\title{
Regulation of 6-Phosphogluconate Dehydrogenase in Brevibacterium flavum
}

\author{
Shin-ichi Sugimoto and Isamu Shiı \\ Central Research Laboratories, Ajinomoto Co., Inc., \\ Kawasaki-ku, Kawasaki, Kanagawa 210, Japan
}

Received August 25, 1986

\begin{abstract}
6PG dehydrogenase (EC 1.1.1.44), partially purified from Brevibacterium flavum, was specific to $\mathrm{NADP}^{+}$, stabilized by $\mathrm{KCl}$, and had an optimum $\mathrm{pH}$ of 7.5 to 8.0 . Its activity was inhibited by FBP, PRPP, GAP, oxaloacetate, E4P, acetyl-CoA, Ru5P, and NADPH, among which, FBP showed the strongest inhibition. The concentrations of the latter giving 50 and $100 \%$ inhibition were 0.07 and $1.0 \mathrm{mM}$, respectively. Inhibition by FBP, PRPP, and E4P was competitive to $6 \mathrm{PG}$ but not to NADP ${ }^{+}$. Homotropic interaction of $6 \mathrm{PG}$ was observed in the presence of FBP and the Hill coefficient was estimated to be 1.6. Inhibition by the reaction products, Ru5P and NADPH, was mixed and noncompetitive to $6 \mathrm{PG}$ and noncompetitive and mixed to $\mathrm{NADP}^{+}$, respectively. Combination of acetyl-CoA with FBP or PRPP inhibited the enzyme synergistically and that of acetyl-CoA with GAP or Ru5P did cumulatively. The sensitivities of the enzyme to the FBP, PRPP, acetyl-CoA, oxaloacetate, and E4P inhibitions were lost with ammonium sulfate treatment. The enzyme was induced by gluconate. Cells grown on gluconate did not contain an FBP-insensitive and NAD-specific enzyme at all.
\end{abstract}

From the results of previous experiments with ${ }^{14} \mathrm{C}$-labeled glucoses, ${ }^{1,2)}$ the pentose phosphate pathway in Brevibacterium flavum seems not to be a main route for glucose metabolism but seems to operate to supply E4P and PRPP, precursors for aromatic amino acid and nucleic acid biosynthesis. Since some mutants of B. flavum have been bred for aromatic amino aicd production, ${ }^{3)}$ it is interesting to elucidate the regulatory mechanisms for the biosyntheses of these precursors. As described in the previous paper, ${ }^{4)}$ G6P dehydrogenase, the first-step enzyme of the pentose phosphate pathway, was found to be an allosteric enzyme which was inhibited by oxaloacetate, FBP, and PRPP. It was also found that the enzyme was induced by glucose.

This paper deals with control of the activity of and the synthesis of $6 \mathrm{PG}$ dehydrogenase, the third-step enzyme of the pathway, which has been reported to be inhibited by FBP in other microorganisms. ${ }^{5 \sim 8)}$ The results obtained were compared with those for G6P dehydrogenase in the previous paper. ${ }^{4)}$

\section{MATERIALS AND METHODS}

Qrganism and media. Brevibacterium flavum No. 2247 (ATCC 14067) was used.

The compositions of Medium $13^{9)}$ and $40^{4)}$ were given in the previous papers.

Chemicals. 6PG, FBP, $\mathrm{NADP}^{+}$, and NADPH were purchased from Boehringer-Mannheim and PRPP, E4P, and Ru5P were from Sigma Chemical Co. Other chemicals used in Table II were purchased from Sigma Chemical Co. or Boehringer-Mannheim.

Enzyme preparation. Cells of B, flavum No. 2247 cultured at $30^{\circ} \mathrm{C}$ for $24 \mathrm{hr}$ in Medium 13 were harvested, washed twice with $0.2 \% \mathrm{KCl}$, suspended in $0.1 \mathrm{M}$ Tris $-\mathrm{HCl}$

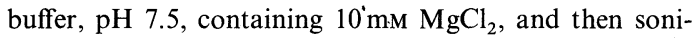
cally disrupted at $10 \mathrm{kc}$ for $20 \mathrm{~min}$. The supernatant solution of the sonicate obtained on centrifugation at

Abbreviations: 6PG, 6-phosphogluconate; G6P, glucose 6-phosphate; TES, $N$-tris(hydroxymethyl)methylaminoethane sulfonic acid; FBP, fructose 1,6-bisphosphate; PRPP, phosphoribosyl pyrophosphate; Ru5P, ribulose 5phosphate; GAP, glyceraldehyde 3-phosphate; E4P, erythrose 4-phosphate; acetyl-CoA, acetyl coenzyme A. 
$32,000 \times g$ for $30 \mathrm{~min}$ was applied on a DEAE-cellulose column $(2.5 \times 22 \mathrm{~cm}$, Whatman DE-52), equilibrated with $0.05 \mathrm{M}$ Tris- $\mathrm{HCl}$ buffer, $\mathrm{pH} 7.5$, containing $30 \mathrm{~mm} \mathrm{MgCl}_{2}$. The column was washed with $100 \mathrm{ml}$ of the same buffer. The enzyme was eluted with a $\mathrm{KCl}$ concentration gradient formed with $500 \mathrm{ml}$ of the same buffer and that containing $0.4 \mathrm{M} \mathrm{KCl}$. Fractions of $8 \mathrm{ml}$ were collected in test tubes, to which $\mathrm{KCl}$ solution was added before the elution to give a final concentration of $0.5 \mathrm{M}$. The fractions containing 6PG dehydrogenase were pooled, concentrated with a ultrafiltration apparatus (Amicon PM-10) and used as the enzyme preparation.

Assay methods. 6PG dehydrogenase was assayed by continuously measuring the increase in absorbancy at $340 \mathrm{~nm}$ of the reaction product, NADPH. The reaction mixture contained $50 \mathrm{~mm}$ TES-NaOH buffer, $\mathrm{pH} 7.5$, $2 \mathrm{~mm} 6 \mathrm{PG}, 0.5 \mathrm{~mm}$ NADP, $10 \mathrm{~mm} \mathrm{MgCl}_{2}$, and the enzyme in a total volume of $0.5 \mathrm{ml}$. One unit of the enzyme activity was defined as the amount catalyzing the formation of $1 \mathrm{nmol}$ of NADPH per min.

Protein was determined by the method of Lowry et al. ${ }^{10)}$

\section{RESULTS}

\section{General properties}

As shown in Table I, whereas 6PG dehydrogenase activity was recovered almost completely when transferred to Tris- $\mathrm{HCl}$ buffer, $\mathrm{pH} 7.5$, by gel-filtration, it decreased to $14 \%$ during storage at $5^{\circ} \mathrm{C}$ for $24 \mathrm{hr}$. The enzyme, as well as G6P dehydrogenase, ${ }^{4)}$ was stabilized by the addition of $0.5 \mathrm{M} \mathrm{KCl}$ or $10 \mathrm{~mm} \mathrm{MgCl}_{2}$.

\section{Table I. Stability of 6-Phosphogluconate DEHYDROGENASE'}

A cell-free extract prepared as described under MATERIALS AND Methods, was passed through a Sephadex G-25 column $(1.5 \times 5 \mathrm{~cm})$ equilibrated with $0.05 \mathrm{M}$ Tris- $\mathrm{HCl}$ buffer, $\mathrm{pH} 7.5$, containing the additions indicated in the table. The activities were measured under the standard assay conditions just after the gel-filtration and after storage at $5^{\circ} \mathrm{C}$ for $24 \mathrm{hr}$. The relative activity with respect to $0 \mathrm{hr}$ is given in the table. The specific activity of the cell-free extract was 175 units/mg protein.

\begin{tabular}{lcc}
\hline Addition to buffer & $\begin{array}{c}\text { Specific activity } \\
\text { (units/mg } \\
\text { protein) }\end{array}$ & $\begin{array}{c}\text { Relative activity } \\
\text { after } 24 \mathrm{hr} \\
\text { at } 5^{\circ} \mathrm{C}(\%)\end{array}$ \\
\hline None & 168 & 14 \\
$0.5 \mathrm{M} \mathrm{KCl}$ & 175 & 89 \\
$10 \mathrm{mM} \mathrm{MgCl}$ & 173 & 41 \\
$1 \mathrm{mM} \mathrm{Dithiothreitol}$ & 156 & 17 \\
\hline
\end{tabular}

$\mathrm{KCl}$ showed a greater stabilizing effect than $\mathrm{Mg}^{2+}$. Then, the enzyme was partially purified in the presence of $\mathrm{KCl}$ and $\mathrm{Mg}^{2+}$ from a cellfree extract by DEAE-cellulosie column chromatography. It was eluted from the column with $0.15 \mathrm{M} \mathrm{KCl}$ and purified 7 -fold with a $55 \%$ yield.

The enzyme reaction depended completely on the substrates, 6PG and NADP ${ }^{+}$, and did not proceed with $\mathrm{NAD}^{+}$instead of $\mathrm{NADP}^{+}$. $\mathrm{Mg}^{2+}$ was not essential but stimulated the activity $22 \%$ at $10 \mathrm{~mm}$.

The optimum $\mathrm{pH}$ of the reaction was 7.5 to 8.0 with TES- $\mathrm{NaOH}$ buffer and 7.5 with Tris$\mathrm{HCl}$ buffer.

The enzyme was confirmed to be 6-phosphoD-gluconate: $\mathrm{NADP}^{+}$3-oxidoreductase (decarboxylating) (EC 1.1.1.44) and not 6phospho-D-gluconate : NAD $(\mathrm{P})^{+}$2-oxidoreductase (EC 1.1.1.43), which forms 2-keto6-phosphogluconate as a reaction product, because no ketoacid was detected by the method of MacGee and Doudoroff. ${ }^{12)}$

Figure 1 shows double reciprocal plots of the reaction rate against the concentrations of the two substrates. The plots gave straight parallel lines, indicating that the reaction mechanism was of the ping pong type. The

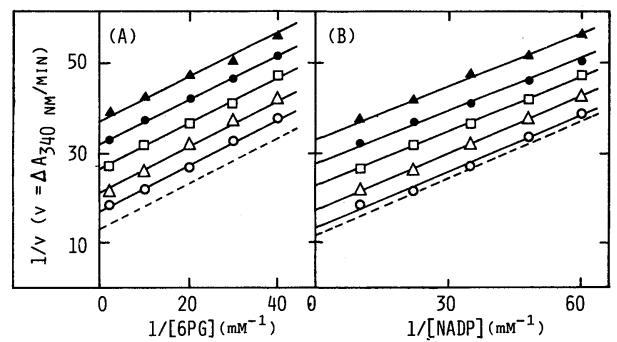

FIG. 1. Double Reciprocal Plots of the 6-Phosphogluconate Dehydrogenase Reaction Rate Against the Substrate Concentration.

The activity was assayed under the standard conditions except for the substrate concentration. In (A), the NADP ${ }^{+}$ concentrations were 0.10 ( $-\mathrm{O}-), 0.0454$ ( $-\triangle-)$, 0.0287 (一 $\square$-), 0.0208 (一- - ), and $0.0167 \mathrm{~mm}(-\boldsymbol{\Delta}-)$. ----, secondary plots of the intercept at the vertical line of (B). In (B), the 6PG concentrations were $0.5(-\mathrm{O}-)$, $0.10(-\triangle-), 0.05(-\square-), 0.033(-\bigcirc-)$, and $0.025 \mathrm{~mm}$ $(-\boldsymbol{\Delta}-)$. ----, secondary plots of the intercept at the vertical line of $(\mathrm{A})$. 
$K m s$ for $6 \mathrm{PG}$ and $\mathrm{NADP}^{+}$were calculated from the secondary plots to be 0.045 and $0.036 \mathrm{~mm}$, respectively.

TABle II. EFFects of Metabolites on 6-Phosphogluconate Dehydrogenase

The activity was measured in the presence and absence of the additions under the standard assay conditions, except that the concentrations of $6 \mathrm{PG}$ and $\mathrm{NADP}^{+}$were both $0.15 \mathrm{~mm}$. The activities are expressed as percentages of that without any addition.

\begin{tabular}{|c|c|}
\hline $\begin{array}{l}\text { Addition } \\
(1 \mathrm{~mm})\end{array}$ & $\begin{array}{c}\text { Relative activity } \\
(\%)\end{array}$ \\
\hline None & 100 \\
\hline Ru5P & 26 \\
\hline Xylulose-5P & 77 \\
\hline Ribose-5P & 87 \\
\hline Sedoheptulose-7P & 95 \\
\hline $\mathrm{E} 4 \mathrm{P}$ & 53 \\
\hline PRPP & 19 \\
\hline G6P & 94 \\
\hline Fructose-6P & 78 \\
\hline FBP & 2.0 \\
\hline GAP & 39 \\
\hline Dihydroxyacetone-P & 87 \\
\hline 3-Phosphoglycerate & 86 \\
\hline 2-Phosphoglycerate & 95 \\
\hline Phosphoenolpyruvate & 95 \\
\hline Pyruvate & 93 \\
\hline Acetyl-CoA & 75 \\
\hline Glucose-1P & 95 \\
\hline Glucose 1,6-bisP & 40 \\
\hline Fructose 2,6-bisP & 66 \\
\hline Fructose-1P & 101 \\
\hline Citrate & 82 \\
\hline 2-Oxoglutarate & 96 \\
\hline Succinate & 98 \\
\hline Fumarate & 96 \\
\hline Malate & 95 \\
\hline Oxaloacetate & 51 \\
\hline L-Glutamate & 100 \\
\hline L-Aspartate & 104 \\
\hline ATP & 103 \\
\hline ADP & 103 \\
\hline AMP & 94 \\
\hline GMP & 90 \\
\hline L-Tryptophan & 105 \\
\hline L-Phenylalanine & 99 \\
\hline L-Tyrosine & 97 \\
\hline L-Histidine & 102 \\
\hline NADPH $^{a}$ & 55 \\
\hline $\mathrm{NADH}^{a}$ & 98 \\
\hline
\end{tabular}

Abbreviation: $\mathbf{P}$, phosphate.

a $0.1 \mathrm{mM}$

\section{Regulation of the activity}

Effects of various metabolites on the $6 \mathrm{PG}$ dehydrogenase activity were examined at the same substrate concentrations as used in the previous study on G6P dehydrogenase. ${ }^{4)}$ As shown in Table II, the activity was inhibited by PRPP and E4P, precursors for aromatic amino acid and nucleic acid biosynthesis, as well as by the reaction products, Ru5P and NADPH. It was also inhibited by FBP and GAP among the intermediates of glycolysis, by acetyl-CoA, and by oxaloacetate among the intermediates of the tricarboxylic acid cycle. Since the enzyme preparation did not contain aldolase activity, the inhibition by GAP does not seem to be due to its conversion into FBP in the reaction system. FBP and NADPH showed 98 and $45 \%$ inhibition at 1.0 and $0.1 \mathrm{~mm}$, respectively, being the strongest inhibitors among the metabolites tested. On the other hand, glucose 1,6-bisphosphate and fructose 2,6-bisphosphate showed lower inhibitory effects, suggesting that they operated as analogues of FBP. Purine nucleotides and aro-

\section{TABLE III. COMPARISON OF THE INHIBITION OF 6-Phosphogluconate Dehydrogenase and Glucose-6-Phosphate Dehydrogenase}

6PG dehydrogenase activity was assayed under the standard conditions except that Tris- $\mathrm{HCl}$ buffer, $\mathrm{pH} 7.5$, $0.15 \mathrm{~mm} 6 \mathrm{PG}$, and $0.15 \mathrm{mM} \mathrm{NADP}^{+}$were used. The data for $\mathrm{G} 6 \mathrm{P}$ dehydrogenase were taken from ref. 4.

\begin{tabular}{|c|c|c|}
\hline \multirow[b]{2}{*}{ Addition (1 mM) } & \multicolumn{2}{|c|}{ Relative activity ( $\%$ ) } \\
\hline & $\begin{array}{c}6 \mathrm{PG} \\
\text { dehydrogenase }\end{array}$ & $\begin{array}{c}\text { G6P } \\
\text { dehydrogenase }\end{array}$ \\
\hline None & 100 & 100 \\
\hline Ru5P & 34 & 73 \\
\hline Xylulose-5P & 96 & 74 \\
\hline PRPP & 22 & 63 \\
\hline E4P & 60 & 90 \\
\hline Fructose-6P & 71 & 94 \\
\hline FBP & 0.8 & 60 \\
\hline GAP & 43 & 82 \\
\hline Acetyl-CoA & 68 & 74 \\
\hline Oxaloacetate & 52 & 33 \\
\hline $\mathrm{NADPH}^{a}$ & 53 & 48 \\
\hline
\end{tabular}

Abbreviation: $\mathrm{P}$, phosphate.

a $0.1 \mathrm{~mm}$. 
matic amino acids had no effect on the activity.

The inhibitory effects of various metabolites were compared between 6PG dehydrogenase and G6P dehydrogenase ${ }^{4)}$ as shown in Table III. Most inhibitors of $6 \mathrm{PG}$ dehydrogenase

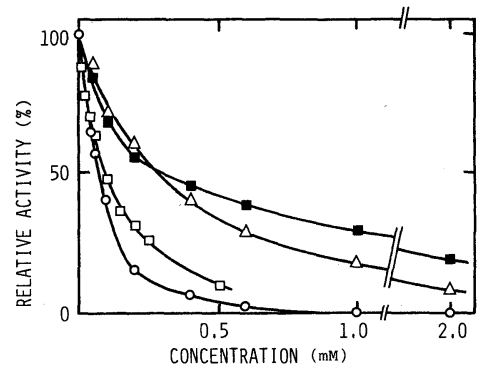

FIG. 2. Effect of the Inhibitor Concentration of 6Phosphogluconate Dehydrogenase Activity.

The activity was assayed in the presence of various concentrations of the inhibitors under the same conditions as those in Table II.

$-\mathrm{O}-$, FBP; 一 $\square-$, NADPH; $-\triangle-$, PRPP; - - , Ru5P.

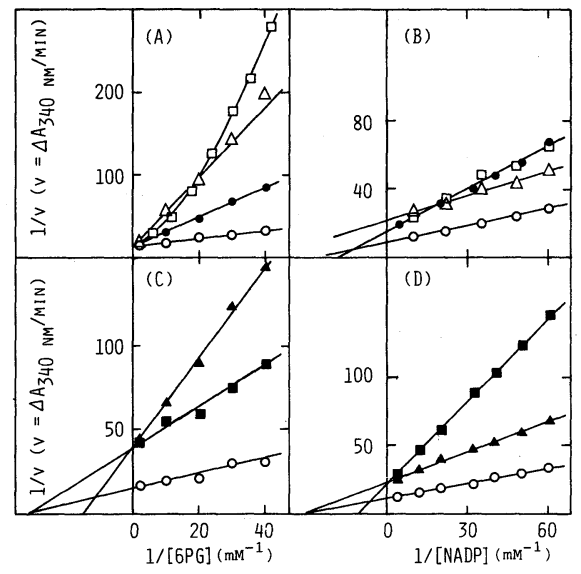

FIG. 3. Double Reciprocal Plots of the 6-Phosphogluconate Dehydrogenase Reaction Rate against the Substrate Concentration in the Presence and Absence of Inhibitors.

The activity was assayed under the standard conditions except for the substrate concentration and the following additions. To the assay mixture, 0.05 mM FBP (A, $-\square-), 0.2 \mathrm{~mm}$ FBP (B, - $\square-$ ), $0.25 \mathrm{~mm}$ PRPP (A, $-\triangle-), \quad 1.0 \mathrm{mM} \quad \mathrm{PRPP} \quad(\mathrm{B},-\triangle-), \quad 1.0 \mathrm{mM} \quad \mathrm{E} 4 \mathrm{P}$ $(--), \quad 0.1 \mathrm{~mm}$ NADPH (-口-), $1.0 \mathrm{~mm} \quad \mathrm{Ru} 5 \mathrm{P}$ (- - -), or nothing (-O-) was added. In (A) and (C), the concentration of NADP was $0.1 \mathrm{~mm}$, and that of $6 \mathrm{PG}$ was $0.5 \mathrm{~mm}$ in (B) and (D). were common to those of G6P dehydrogenase. However, the inhibition of 6PG dehydrogenase by metabolites other than xylulose 5phosphate, oxaloacetate, and NADPH was stronger than that of G6P dehydrogenase.

Figure 2 shows the effects of the concentrations of FBP, PRPP, Ru5P, and NADPH on the activity. FBP showed the strongest inhibition at any concentration among the inhibitors tested and inhibited the activity completely at $1.0 \mathrm{~mm}$. The concentrations of FBP, NADPH, PRPP, and Ru5P giving 50\% inhibition were estimated to be $0.07,0.09,0.28$, and $0.30 \mathrm{~mm}$, respectively.

Figure 3 shows double reciprocal plots of the reaction rate against the substrate concentration in the presence and absence of inhibitors. The inhibition by FBP, PRPP, and E4P was competitive to 6PG but not competitive to NADP (Fig. 3(A, B)). The plots against $6 \mathrm{PG}$ concentration in the presence of FBP curved upwards, indicating the homotropic interaction of $6 \mathrm{PG}$. The Hill coefficient for 6PG was estimated to be 1.6. This result indicates that FBP is an allosteric inhibitor. From these results, the reaction velocity $(v)$ was determined with the following equation:

$$
1 / v=1 / V\left[1+K a / \mathrm{A}^{n}(1+\mathrm{I} / K i)+K b / \mathrm{B}\right],
$$

where $V, \mathrm{~A}, \mathrm{~B}, \mathrm{I}, K a, K b, K i$, and $n$ are the maximum velocity, $6 \mathrm{PG}$ and $\mathrm{NADP}^{+}$concentrations, inhibitor concentration, Michaelis constants for $6 \mathrm{PG}$ and $\mathrm{NADP}^{+}$, inhibitor constant, and Hill coefficient, respectively. When the inhibitor was PRPP or E4P, the Hill coefficient was 1.0. From $(1+\mathrm{I} / \mathrm{Ki})$, the ratio of the slopes in the presence and absence of PRPP or E4P in Fig. 3(A), the inhibitor constants of PRPP and E4P were calculated to be 0.032 and $0.37 \mathrm{~mm}$, respectively. The inhibitor constant of FBP was calculated to be $0.055 \mathrm{~mm}$ with the following Hill equation:

$\log \left(1 / v-1 / v^{\prime}\right)=\log K a / V(1+\mathrm{I} / K i)-n \log \mathrm{A}$,

where $v^{\prime}$ is $1 / V(1+K b / \mathrm{B})$, the intercept at the vertical line in Fig. 3(A). As shown in Fig. 3(C, D), the inhibition by Ru5P or NADPH, a reaction product, was mixed or noncom- 
Table IV. Effect of the Simultaneous Presence OF INHIBITORS ON 6-PHOSPHOGLUCONATE DeHYDROGENASE ACTIVITY

The activity was assayed in the simultaneous presence of two inhibitors under the same conditions as those in Table II. The theoretical values for cumulative inhibition are given in parentheses.

\begin{tabular}{|c|c|c|}
\hline Addition & $\begin{array}{l}\text { Concentration } \\
(\mathrm{mM})\end{array}$ & $\begin{array}{c}\text { Relative } \\
\text { activity } \\
(\%)\end{array}$ \\
\hline None & - & 100 \\
\hline $\begin{array}{l}\text { FBP } \\
\quad+\text { PRPP } \\
\text { + Ru5P } \\
\text { + GAP } \\
\text { + oxaloacetate } \\
\text { + E4P } \\
\text { + acetyl-CoA }\end{array}$ & $\begin{array}{l}0.05 \\
0.05+0.1 \\
0.05+0.1 \\
0.05+0.6 \\
0.05+0.5 \\
0.05+0.5 \\
0.05+1.0\end{array}$ & $\begin{array}{l}66 \\
61(52) \\
52(46) \\
49(41) \\
50(40) \\
57(44) \\
19(46)\end{array}$ \\
\hline $\begin{array}{l}\text { PRPP } \\
\quad+\text { Ru5P } \\
\quad+\text { GAP } \\
\quad+\text { oxaloacetate } \\
\quad+\text { E4P } \\
\text { + acetyl-CoA }\end{array}$ & $\begin{array}{l}0.1 \\
0.1+0.1 \\
0.1+0.6 \\
0.1+0.5 \\
0.1+0.5 \\
0.1+1.0\end{array}$ & $\begin{array}{l}79 \\
62(55) \\
58(49) \\
58(48) \\
65(53) \\
32(54)\end{array}$ \\
\hline $\begin{array}{l}\text { Ru5P } \\
\quad+\text { GAP } \\
\quad+\text { oxaloacetate } \\
\quad+\text { E4P } \\
\quad+\text { acetyl-CoA }\end{array}$ & $\begin{array}{l}0.1 \\
0.1+0.6 \\
0.1+0.5 \\
0.1+0.5 \\
0.1+1.0\end{array}$ & $\begin{array}{l}70 \\
55(44) \\
55(43) \\
59(47) \\
44(49)\end{array}$ \\
\hline $\begin{array}{l}\text { GAP } \\
\quad+\text { oxaloacetate } \\
\quad+\text { E4P } \\
+ \text { acetyl-CoA }\end{array}$ & $\begin{array}{l}0.6 \\
0.6+0.5 \\
0.6+0.5 \\
0.6+1.0\end{array}$ & $\begin{array}{l}63 \\
50(39) \\
50(42) \\
38(43)\end{array}$ \\
\hline $\begin{array}{l}\text { Oxaloacetate } \\
\qquad \begin{array}{l}+\mathrm{E} 4 \mathrm{P} \\
+ \text { acetyl-CoA }\end{array}\end{array}$ & $\begin{array}{l}0.5 \\
0.5+0.5 \\
0.5+1.0\end{array}$ & $\begin{array}{l}62 \\
52(41) \\
54(43)\end{array}$ \\
\hline $\begin{array}{l}\text { E4P } \\
+ \text { acetyl-CoA }\end{array}$ & $\begin{array}{l}0.5 \\
0.5+1.0\end{array}$ & $\begin{array}{l}67 \\
59(46)\end{array}$ \\
\hline Acetyl-CoA & 1.0 & 69 \\
\hline
\end{tabular}

petitive to 6PG and noncompetitive or mixed to $\mathrm{NADP}^{+}$, respectively.

The effects of the simultaneous presence of inhibitors on the enzyme activity are shown in Table IV. Among the seven inhibitors tested, the combination of acetyl-CoA with FBP or PRPP inhibited the activity synergistically, whereas that of acetyl-CoA with GAP or Ru5P did cumulatively.
Table V. Effect of Ammonium Sulfate Treatment ON the SENSITIVITY to INHIBITION AND THE ACTIVITY of 6-Phosphogluconate Dehydrogenase

Ammonium sulfate and EDTA were added to the enzyme preparation to give 0.7 saturation and $80 \mathrm{~mm}$, respectively. After standing overnight at $5^{\circ} \mathrm{C}$, the mixture was dialyzed for $2 \mathrm{hr}$ against $0.05 \mathrm{M}$ Tris- $\mathrm{HCl}$ buffer, $\mathrm{pH}$ 7.5 , containing $0.5 \mathrm{M} \mathrm{KCl}$. Then, the activity was assayed in the presence and absence of each inhibitor under the same conditions as those in Table II. The specific activity was determined under the standard assay conditions.

\begin{tabular}{|c|c|c|c|}
\hline \multirow{2}{*}{ Inhibitor } & \multirow{2}{*}{$\begin{array}{l}\text { Concentration } \\
(\mathrm{mm})\end{array}$} & \multicolumn{2}{|c|}{ Inhibition $(\%)$} \\
\hline & & Treated & Untreated \\
\hline & & $(925)^{a}$ & $(985)^{a}$ \\
\hline FBP & 0.5 & 10 & 96 \\
\hline PRPP & 0.5 & 5 & 72 \\
\hline E4P & 1.0 & 8 & 47 \\
\hline Oxaloacetate & 1.0 & 2 & 49 \\
\hline Acetyl-CoA & 1.0 & 7 & 25 \\
\hline GAP & 1.0 & 51 & 61 \\
\hline Ru5P & 1.0 & 63 & 74 \\
\hline NADPH & 0.2 & 79 & 64 \\
\hline
\end{tabular}

${ }^{a} \quad$ Specific activity (units/mg protein).

\section{Desensitization to the inhibition}

As described previously, ${ }^{4)}$ the sensitivities of G6P dehydrogenase to the oxaloacetate, FBP, and PRPP inhibitions were lost on three-timesrepeated treatments with ammonium sulfate, whereas that to the NADPH inhibition was not. As shown in Table V, when 6PG dehydrogenase was treated once with ammonium sulfate, the inhibition by FBP, PRPP, E4P, acetyl-CoA, and oxaloacetate was markedly reduced, whereas that by GAP and the reaction products, Ru5P and NADPH, as well as the enzyme activity were not affected by the treatment at all. These results suggest that the former five inhibitors bind at site(s) different from the active site of the enzyme and are labile to the ammonium sulfate treatment, although FBP, PRPP, and E4P among these inhibitors inhibit the activity competitively to 6PG. The inhibition by GAP was not affected by the treatment, suggesting that GAP acted at the active site as an analogue of the reaction product, Ru5P. This seems to be supported by 
Table Vi. Effect of the Carbon Source in the Culture Medium on the Activity and Inhibition of 6-Phosphogluconate Dehydrogenase

B. flavum No. 2247 was cultured at $30^{\circ} \mathrm{C}$ for $24 \mathrm{hr}$ with various carbon sources. In Expt. I, Medium 13, containing indicated carbon source and $1.5 \mathrm{~g} / \mathrm{l}$ of urea, was used, while Medium 40, containing indicated carbon source, was used in Expt. II. When glutamate, succinate, and citrate were used as carbon sources in Expt. II, the strain was cultured for $48 \mathrm{hr}$. Cell-free extracts, prepared as described under MATERIALS AND METHODS, were passed through a Sephadex G-25 column $(1.5 \times 5 \mathrm{~cm})$, equilibrated with $0.05 \mathrm{M}$ Tris- $\mathrm{HCl}$ buffer, $\mathrm{pH} 7.5$, containing $0.5 \mathrm{M} \mathrm{KCl}$, and then used as enzyme preparations. The specific activity was determined under the standard assay conditions except that $\mathrm{NADP}^{+}$or $\mathrm{NAD}^{+}$was used. Inhibition by $1 \mathrm{~mm}$ FBP was determined under the same conditions as those in Table II.

\begin{tabular}{|c|c|c|c|c|c|}
\hline \multirow{2}{*}{ Expt. } & \multirow{2}{*}{ Carbon source } & \multirow{2}{*}{$\begin{array}{l}\text { Growth } \\
\left(A_{562 \mathrm{~nm}}\right)\end{array}$} & \multicolumn{2}{|c|}{ Specific activity $^{a}$} & \multirow{2}{*}{$\begin{array}{c}\text { Inhibition } \\
(\%)\end{array}$} \\
\hline & & & NADP & NAD & \\
\hline \multirow[t]{4}{*}{ I } & Glucose & 0.520 & 164 & 0 & 98 \\
\hline & Gluconate & 0.470 & 476 & 0 & 97 \\
\hline & Fructose & 0.410 & 166 & & \\
\hline & Ribose & 0.490 & 185 & & \\
\hline \multirow[t]{7}{*}{ II } & Glucose & 0.410 & 186 & & \\
\hline & Glutamate & 0.380 & 161 & & \\
\hline & Succinate & 0.315 & 143 & & \\
\hline & Citrate & 0.340 & 123 & & \\
\hline & Fumarate & 0.225 & 152 & & \\
\hline & Acetate & 0.530 & 84 & & \\
\hline & Lactate & 0.460 & 109 & & \\
\hline
\end{tabular}

a Units/mg protein.

the fact that GAP as well as Ru5P inhibits the activity cumulatively in combination with acetyl-CoA.

\section{Regulation of the enzyme synthesis}

The effect of the carbon source in the medium on the specific activity was examined in order to elucidate the regulation mechanism for the enzyme synthesis. As shown in Table VI, cells grown on gluconate as a carbon source showed specifically 2 -fold higher activity than those grown on glucose. This result suggests the induction by gluconate. An FBPinsensitive and $\mathrm{NAD}^{+}$-specific $6 \mathrm{PG}$ dehydrogenase, such as that which has been reported to be induced by gluconate in Streptococcus faecalis, ${ }^{11)}$ was not found at all in the cell-free extract prepared from $B$. flavum cells grown on gluconate or glucose. Furthermore, the sensitivity of the $\mathrm{NADP}^{+}$-specific enzyme to the FBP inhibition was not affected by carbon sources (Table VI).

\section{DISCUSSION}

The 6PG dehydrogenase of B. flavum was inhibited by various metabolites, such as FBP, PRPP, GAP, oxaloacetate, E4P, and acetyl$\mathrm{CoA}$, in addition to the reaction products, Ru5P and NADPH. Furthermore, the homotropic interaction of the substrate was observed in the presence of FBP. In contrast to the sensitivities to the Ru5P and NADPH inhibitions, those to the FBP, PRPP, E4P, oxaloacetate, and acetyl-CoA inhibitions were lost with ammonium sulfate treatment, which did not affect the activity. The combination of acetyl-CoA with FBP or PRPP inhibited the activity synergistically and that of acetyl-CoA with GAP or Ru5P did cumulatively. These results indicate that at least five of the inhibitors tested, FBP, PRPP, E4P, oxaloacetate, and acetyl-CoA, are allosteric inhibitors.

FBP showed the strongest inhibition among 
the inhibitors tested, the concentrations giving $50 \%$ and complete inhibition being 0.07 and $1.0 \mathrm{~mm}$, respectively. Moreover, the inhibition by FBP was synergistically enhanced in the simultaneous presence of acetyl-CoA. Therefore, the results strongly suggest the operation of the inhibition under the physiological conditions. The inhibition of $6 \mathrm{PG}$ dehydrogenase seems to have the following physiological significance; the inhibition by PRPP and E4P constitutes a feedback inhibition of their biosynthesis, that by FBP, GAP, and oxaloacetate constitutes feedback control of the central carbon metabolism, and those by Ru5P and NADPH are product inhibitions. Therfore, the supply of PRPP and E4P as raw materials for aromatic amino acid production by Brevibacterium mutants seems to be regulated by both these feedback inhibitions and the feedback control as central carbon metabolism.

As described in the previous paper, ${ }^{4)}$ G6P dehydrogenase, the first-step enzyme in the pentose phosphate pathway, was also specific to $\mathrm{NADP}^{+}$, stabilized by $\mathrm{KCl}$ and inhibited by metabolites such as oxaloacetate, FBP, PRPP, acetyl-CoA, Ru5P, and NADPH. Furthermore, the sensitivities to the oxaloacetate, FBP, and PRPP inhibitions were lost with ammonium sulfate treatment. Therefore, these results indicate that $6 \mathrm{PG}$ dehydrogenase and G6P dehydrogenase have common properties and that the two reactions in the initial part of the pentose phosphate pathway in B. flavum are regulated in a similar manner. However, 6PG dehydrogenase was much more strongly inhibited by FBP, GAP, PRPP, and E4P than G6P dehydrogenase. Most of these inhibitions were competitive to the substrate in contrast to those of G6P dehydrogenase, suggesting that these inhibitions might be further enhanced at lower substrate concentrations.

6PG dehydrogenases from many other microorganisms ${ }^{5 \sim 8)}$ have also been found to be inhibited by FBP, but only partially, ${ }^{5}$ in contrast to that from B. flavum. On the other hand, ATP, which often inhibits the enzymes from other microorganisms, ${ }^{8,11)}$ did not affect that from B. flavum. The inhibitions by PRPP, E4P, GAP, and oxaloacetate found in $B$. $f l a-$ vum have not been found in any other microorganisms.

The induction of 6PG dehydrogenase by gluconate was seen in B. flavum. The induced enzyme was $\mathrm{NADP}^{+}$-specific and FBP-sensitive in contrast to the $S$. faecalis enzyme, which is $\mathrm{NAD}^{+}$-specific and FBP-insensitive. ${ }^{11)}$ When $B$. flavum grows on gluconate, the pentose phosphate pathway seems to have two functions, that is, central carbon metabolism and supplying precursors for aromatic amino acid and nucleic acid biosynthesis. Therefore, the central carbon metabolism could be strongly regulated by these intermediate metabolites. However, since these feedback inhibitions are competitive to the substrate, 6PG, they seem to be considerably reduced by a possibly higher level of 6PG generated from gluconate as the carbon source than from glucose.

Acknowledgments. The authors are indebted to Drs. H. Okada, Y. Komachiya, and R. Tsugawa for their encouragement during this study.

\section{REFERENCES}

1) I. Shiio, S. Otsuka and T. Tsunoda, J. Biochem., 47, 414 (1960).

2) I. Shiio, S. Otsuka and T. Tsunoda, J. Biochem., 46, 1303 (1959).

3) I. Shiio, S. Sugimoto and K. Kawamura, Agric. Biol. Chem., 48, 2073 (1984).

4) S. Sugimoto and I. Shiio, Agric. Biol. Chem., 51, 101 (1987).

5) A. T. Brown and C. L. Wittenberger, J. Bacteriol., 106, 456 (1971).

6) W. A. Scott and T. A. Bramsky, J. Biol. Chem., 248, 3535 (1971).

7) R. E. Wolf, Jr. and F. M. Shea, J. Bacteriol., 138, 171 (1979).

8) O. Adachi, K. Osada, K. Matsushita, E. Shinagawa and M. Ameyama, Agric. Biol. Chem., 46, 391 (1982).

9) I. Shiio and K. Ujigawa, J. Biochem., 84, 647 (1978).

10) O. H. Lowry, N. J. Rosebrough, A. L. Farr and R. J. Randall, J. Biol. Chem., 193, 265 (1951).

11) A. T. Brown and C. L. Wittenberger, J. Bacteriol., 109, 106 (1972).

12) J. MacGee and M. Doudoroff, J. Biol. Chem., 210, 617 (1954). 